\title{
PERILAKU KEKUATAN BETON DENGAN PARTIKEL GELAS DAN KARET BAN BEKAS SEBAGAI PENGGANTI PASIR ALAM
}

\author{
(Strength Behaviour of Concrete Containing Glass and Tyre Rubber Particles as \\ Replacement of Natural Sand)
}

\author{
Sandy I. Yansiku ${ }^{1}$ \\ ${ }^{1}$ Program Studi Teknik Sipil, Fakultas Teknik, Universitas Nusa Nipa \\ Jln. Kesehatan No.3 Maumere, Nusa Tenggara Timur, Indonesia \\ Penulis korespondensi: Sandy I. Yansiku, email: sandyyansiku@yahoo.com
}

Diterima: 23 Februari 2017

Disetujui: 17 Maret 2017

\begin{abstract}
This paper presents the results of experimental investigation into the behaviour of concrete mixed with recycled-based materials as partial replacement of natural sand. Various properties: compressive, split tensile and flexural strength were investigated through either single or combination replacement categories in which glass sand, rubber sand, and recycled concrete aggregate were specifically proportioned.Test results indicate that certain replacement types of possibly achieve sufficient strength and physical behaviour to replace normal concrete. Single replacements typically generate higher compressive, tensile and flexural strength than combination types. Concrete with lower content of alternative material exhibited comparable strength relative to the original concrete. The workability of higher angular surface material such as glass sand and rubber sand generated higher workability.
\end{abstract}

Keywords: concrete strength; glass; rubber; particles; replacement

\section{PENDAHULUAN}

Kemajuan teknologi beton semakin meluas dengan meningkatnya berbagai pilihan kombinasi campuran material sebagai pengganti semen Portland, pasir beton dan agregat kasar guna menghasilkan kekuatan dan kemampuan layan yang memadai bagi struktur bangunan. Di samping keuntungannya pada struktur bangunan, beton memiliki beberapa kekurangan seperti kuat tarik yang lebih kecil dibandingkan struktur baja, kecilnya rasio kekuatan terhadap beratnya, daktilitas rendah, rentan terhadap retak dan dampaknya terhadap lingkungan sebagai akibat dari tingginya emisi karbon dalam proses produksi semen, yang memiliki kontribusi sebesar 9.5\% terhadap emisi karbondioksida global (Oliver, Maenhout dan Muntean, 2014). Sehingga selain pertimbangan ekonomi, diperlukan pemanfaatan konstruksi beton yang ramah lingkungan dari material bekas pakai dan mampu memikul beban struktur bangunan.

Karakteristik material bekas pakai dalam bentuk partikel seperti gelas/kaca (waste glass sand, GS) dan ban karet bekas kendaraan bermotor (waste tyre rubber sand, TS) telah terbukti mampu menggantikan material beton konvensional ${ }^{1}$. Meskipun beton dengan modifikasi komposisi material menunjukkan karakteristik kekuatan yang lebih rendah, keterbatasan tersebut dapat direduksi dengan mekanisme penggantian ganda yang memungkinkan terciptanya mutu beton yang memuaskan. Langkah ini secara praktis merupakan pilihan yang menjanjikan dalam memperbaiki daya dukung beton dan mempromosikan konstruksi yang ramah lingkungan. Tujuan penelitian ini adalah menentukan karakteristik kekuatan beton yang tersusun atas

\footnotetext{
${ }^{1}$ Shayan A dan Xu A (2004), Batayneh M, Marie I, Asi I (2007), Batayneh M, Marie I, Asi I (2008), Ismail ZZ, AlHashmi EA (2009), Limbachiya MC (2009), Borhan TM (2012), Malik MI et al. (2013).
} 
material bekas pakai sebagai pengganti pasir alam dalam campuran adukan beton.

\section{LITERATURE REVIEW}

Berbagai penelitian tentang pemanfaatan GS sebagai pengganti pasir alam telah dilakukan dan menghasilkan karakteristik kekuatan yang bervariasi. Penelitian yang dilakukan oleh Shayan dan Xu (2006) dan Taha dan Nounu (2008) menunjukkan penurunan kekuatan tekan beton sebesar $10 \mathrm{MPa}$. Sebaliknya, hasil penelitian oleh Batayneh, Marie dan Asi (2007) menunjukkan peningkatan linier kuat tekan beton dari $32 \mathrm{MPa}$ ke $43 \mathrm{MPa}$ akibat perbedaan kekuatan dan tekstur permukaan pasir alam dan kaca. Modulus elastisitas beton dengan kandungan pasir kaca menurun dengan adanya penambahan $50 \%$ pasir kaca dalam campuran beton (Ali dan AlTersawy, 2012). Proporsi penggantian maksimum dianjurkan sebesar 20\% untuk memperoleh kuat tekan beton optimal (Malik et al., 2013), kuat tarik (Borhan, 2012) dan kuat lentur (Ismail dan Al-Hashmi, 2009) dari beton GS. Peningkatan kuat lentur dapat mencapai $50 \%$ lebih besar dari beton konvensional apabila rasio penggantian melebihi 50\% (Shayan dan Xu, 2004). Daya tahan beton GS sebanding dengan daya tahan beton normal pada rasio penggantian 15\% (Limbachiya, 2009). Susut kering beton GS dapat direduksi dengan penggantian $45 \%$ pasir alam dengan GS. Perubahan panjang beton normal sebesar $0.0038 \%$ yang lebih besar dibandingkan dengan beton pasir kaca sebesar $0.0031 \%$ (Kou dan Poon, 2009). Eksperimen yang dilakukan pada partikel tube kaca katode menggantikan pasir alam oleh Ling dan Poon (2011) menunjukkan susut kering yang masih dalam rentang standar. Daya serap air beton normal ialah sebesar $1.2 \%$ dan dengan peningkatan jumlah pasir kaca sebesar $40 \%$ daya serap air menurun ke
0.52\% (Malik et al., 2013). Hal ini dapat disebabkan oleh karakteristik material kaca yang sulit tembus air.

Evaluasi penggantian 5\%, 10\%, $15 \%$ dan $20 \%$ pasir alam dengan partikel karet bekas menunjukkan variasi karakteristik kekuatan beton sebagai akibat dari perbedaan ukuran partikel, volume, ukuran spesimen dan beban kerja ${ }^{2}$. Meskipun demikian, penurunan kuat tekan beton berkisar antara $15 \%$ sampai $20 \%$, kuat tarik rerata $7 \%$ sampai $13 \%$ dan kuat lentur 9\% sampai $23 \%$ tiap penambahan $5 \%$ TS. Komposisi yang tepat dalam campuran beton TS dapat meningkatkan kapasitas penyerapan energi, deformasi dan redaman ijin (Warudkar dan Valekar, 2015). Pencampuran TS lebih dari 50\% secara signifikan menurunkan kuat tekan sebesar 50\% dan kuat tarik sebesar $60 \%$ tanpan mempertimbangkan perlakuan tambahan pada material karet (Siddique dan Naik, 2004). Dengan substitusi 5\%, 10\%, 15\% dan 20\% mereduksi $15 \%$ sampai $20 \%$ kuat tekan, $7 \%$ sampai $13 \%$ kuat tarik dan $9 \%$ to 23\% kuat lentur (Bravo dan Brito, 2012).

Penyusutan beton dengan partikel karet meningkat setiap penambahan 5\% TS karena hilangnya ikatan antara permukaan partikel karet dan matriks semen pada observasi umur beton 28 hari dan 90 hari. Para peneliti menganjurkan penambahan $\mathrm{NaOH}$ dalam campuran beton TS untuk mempertinggi daya lekat antar partikel sehingga meningkatkan kekuatan dan mereduksi porositas ${ }^{3}$. Retak jangka panjang dapat juga dikurangi dengan metode tersebut karena daya susut yang minimal (Vu, Turatsinze dan Ho, 2008). Pada rasio 5\% tidak terdapat pengaruh buruk yang berarti karena penetrasi air hanya mencapai $12 \mathrm{~mm}$ sedangkan

\footnotetext{
${ }^{2}$ Bravo M dan Brito JD (2012), Nithiya P dan Portchejian G (2014), Thomas BS et al. (2014).

${ }^{3}$ Bravo M, Brito JD (2012) dan Yung WH, Yung LC, dan Hua LH (2013).
} 
apabila rasio ditingkatkan menjadi $20 \%$ penetrasi air meningkat tiga kalinya. Sementara itu pada level $20 \%$ beton TS menunjukkan daya tahan terhadap abrasi yang lebih baik karena partikel mencuat ke permukaan sehingga menahan pengikisan beton (Thomas et al., 2014).

\section{METODE PENELITIAN}

Dalam penelitian ini terdapat tiga kelompok campuran/mix yakni kelompok pertama mencakup campuran untuk beton normal dan disebut grup kontrol dan dua kelompok lainnya adalah campuran beton dengan GS dan TS yang disebut grup modifikasi. Grup kontrol diberi notasi CC40 merupakan spesimen standar yang digunakan sebagai acuan karakteristik kekuatan beton terhadap grup modifikasi. Kelompok kedua terdiri dari campuran beton GS dengan rasio penggantian $100 \%$ dan diberi notasi GS100, sedangkan kelompok ke tiga yang mencakup beton GS dengan tiga rasio panggantian $(10 \%, 20 \%$ dan $30 \%)$ dan diberi notasi R1, R2 and R3. Target kuat tekan beton adalah $40 \mathrm{Mpa}$ untuk semua spesimen.

\section{Matriks Spesimen}

Spesimen yang digunakan dalam penelitian ini berbentuk silinder dengan diameter $100 \mathrm{~mm}$ dan tinggi $200 \mathrm{~mm}$. Komposisi campuran adukan beton disajikan dalam Tabel 1.

\section{Material}

Semen Portland disediakan oleh Adelaide Brighton Cement Ltd, pasir kaca disediakan oleh laboratorium University of Adelaide sedangkan pasir karet berukuran lolos saringan nomor 40 disumbangkan oleh Tyrecycle Melbourne. Kandungan kimia GS disajikan dalam Tabel 2.

Tabel 2. Komposisi Kimia GS

\begin{tabular}{lc}
\hline Jenis & Kandungan (\%) \\
\hline $\mathrm{SiO}_{2}$ & 72.5 \\
$\mathrm{Al}_{2} \mathrm{O}_{3}$ & 0.4 \\
$\mathrm{Fe}_{2} \mathrm{O}_{3}$ & 0.2 \\
$\mathrm{CaO}$ & 9.7 \\
$\mathrm{MgO}$ & 3.3 \\
$\mathrm{Na}_{2} \mathrm{O}$ & 13.7 \\
$\mathrm{~K}_{2} \mathrm{O}$ & 0.1 \\
\hline
\end{tabular}

Terdapat 4 jenis ukuran partikel GS yang berbeda dalam paket material yang ada yakni 0-0.3 mm, 0.3-1.0 mm, 1.0-1.5 $\mathrm{mm}$ and 1.5-4.0 mm. Guna pemerataan ukuran partikel sesuai distribusi ukuran butir pasir beton maka persentase berat GS untuk tiap jenis ukuran tersebut di distribusikan sebesar $25 \%, 25 \%, 20 \%$ and $30 \%$ masingmasingnya.

\section{Proporsi Campuran Beton Normal}

Desain campuran beton normal mangandung $375 \mathrm{~kg} / \mathrm{m}^{3}$ semen, 740 $\mathrm{kg} / \mathrm{m}^{3}$ pasir, $1110 \mathrm{~kg} / \mathrm{m}^{3}$ agregat kasar dan $232 \mathrm{~kg} / \mathrm{m}^{3}$ air tanpa zat additif/superplasticizer.

Tabel 1. Test Matrix

\begin{tabular}{lccccc}
\hline \multicolumn{1}{c}{ Notasi } & Agregat Kasar & \multicolumn{4}{c}{ Agregat Halus (\%) } \\
\cline { 3 - 6 } Spesimen & $(\%)$ & TS & GS & Pasir Alam & Semen \\
\hline CC40 & 100 & 0 & 0 & 100 & 100 \\
R1 & 100 & 10 & 0 & 90 & 100 \\
R2 & 100 & 20 & 0 & 80 & 100 \\
R3 & 100 & 30 & 0 & 70 & 100 \\
GS100 & 100 & 0 & 100 & 0 & 100 \\
\hline
\end{tabular}


Standar Uji

Empat jenis pengujian yang dilakukan dalam penelitian ini berupa uji konsistensi (slump test), uji kuat tekan, uji kuat tarik dan uji kuat lentur berdasarkan standar ASTM seperti yang disajikan dalam Tabel 3. beton normal CC40, sedangkan kepadatan beton modifikasi lebih kecil dari beton normal meskipun penurunan hanya mencapai maksimum $6 \%$ seperti yang ditunjukkan dalam Tabel 4.

\section{Kuat Tekan}

Tabel 3. Standar Uji

\begin{tabular}{|lccc|}
\hline \multicolumn{1}{|c}{ Jenis Uji } & $\begin{array}{c}\text { Standar } \\
\text { Acuan }\end{array}$ & $\begin{array}{c}\text { Umur Beton } \\
\text { (hari) }\end{array}$ & $\begin{array}{c}\text { Tipe } \\
\text { Spesimen }\end{array}$ \\
\hline Slump & ASTM C143 & - & - \\
Kuat Tekan & ASTM C39-10 & $3,7,28,128$ & Silinder \\
Kuat Tarik & ASTM C496-04 & 28 & Silinder \\
Kuat Lentur & ASTM C78 & 28 & Prisma \\
\hline
\end{tabular}

Tabel 4. Perubahan Nilai Slump dan Kepadatan

\begin{tabular}{lccccc|}
\hline \multirow{2}{*}{ Material } & Kode & Rasio & \multirow{2}{*}{ Slump } & \multicolumn{2}{c|}{ Kepadatan } \\
\cline { 5 - 6 } & Spesimen & substitusi & & Fresh & Hardened \\
\hline Normal mix & CC40 & $0 \%$ & $0 \%$ & $0 \%$ & $0 \%$ \\
Glass sand & GS100 & $100 \%$ & $28 \%$ & & \\
Rubber & R1 & $10 \%$ & $-3 \%$ & $-2.5 \%$ & $-3.15 \%$ \\
& R2 & $20 \%$ & $31 \%$ & $-3.7 \%$ & $-3.61 \%$ \\
& R3 & $30 \%$ & $42 \%$ & $-5.7 \%$ & $-5.04 \%$ \\
\hline
\end{tabular}

Mesin uji yang digunakan adalah SEIDNER multitasking machine yang dapat melakukan tiga jenis uji kekuatan beton. Besarnya beban yang diaplikasikan pada mesin uji ialah 400 $\mathrm{kN}$ dengan load rate 39\% untuk uji kuat tekan dan $12.5 \%$ untuk uji kuat tarik. Dalam penelitian ini digunakan 3 sampel untuk setiap jenis pengujian sehingga hasil pengujian merupakan nilai rerata dari ketiga sampel tersebut.

\section{HASIL DAN PEMBAHASAN}

\section{Konsistensi dan Kepadatan}

Nilai slump spesimen R2, R3 dan GS100 meningkat dibandingkan dengan

\begin{abstract}
Gambar 1 menunjukkan penurunan linier kuat tekan beton spesimen R1, R2 dan R3 pada umur 28 hari. Beton dengan kandungan partikel karet mengalami penurunan kuat tekan pada semua rasio substitusi dan semua umur beton yang dikaji dalam penelitian ini. Kuat tekan spesimen R1 11.8\% lebih rendah dari CC40, sementara kuat tekan R2 lebih kecil 21\% dan R3 28.7\%. Hasil ini menunjukkan karakteristik beton yang berbeda dengan observasi yang dilakukan oleh [14, 15], karena penelitian ini menggunakan partikel karet dengan ukuran butir yang lebih kecil $(0.075 \mathrm{~mm})$ di mana derajat penurunan seharusnya tidak signifikan.
\end{abstract}




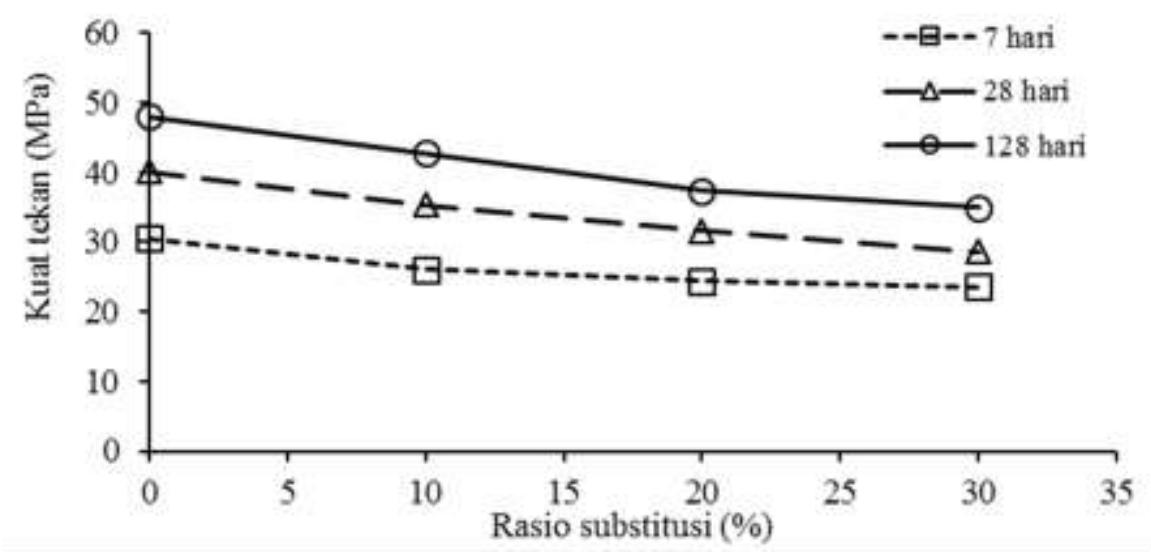

Gambar 1. Kuat Tekan Beton Spesimen R1, R2 dan R3

Dengan penggantian seluruh pasir alam dengan GS, penurunan kuat tekan beton modifikasi GS100 dalam usia 7 hari hampir mencapai $50 \%$ dan berangsur-angsur menguat di usia 28 hari seperti yang ditunjukkan dalam Gambar 2.

Kekuatan beton mengalami peningkatan seiring dengan bertambahnya umur beton. Pada usia 28 hari kuat tekan CC40 mencapai target $40 \mathrm{MPa}$ sedangkan spesimen lain belum mencapai target. Pada umur 128 hari kuat tekan beton R1 melampaui $40 \mathrm{Mpa}$ diikuti dengan R2 dan R3. Rusaknya sampel beton spesimen GS100 pada umur 128 hari menyebabkan penulis tidak dapat menyajikan data kuat tekan spesimen tersebut pada Gambar 3.

\section{Kuat Tarik}

Seperti terlihat pada Gambar 4., dampak negatif $10 \%$ dan $30 \%$ penggantian pasir natural dengan TR pada spesimen R1 dan R3 dapat diabaikan karena kuat tarik spesimen ini menyamai kuat tekan sampel konvensional. Penurunan kuat tarik yang nyata terjadi pada R2 di mana kuat tarik spesimen ini berkurang $0.69 \mathrm{MPa}$ atau sebesar $17 \%$.

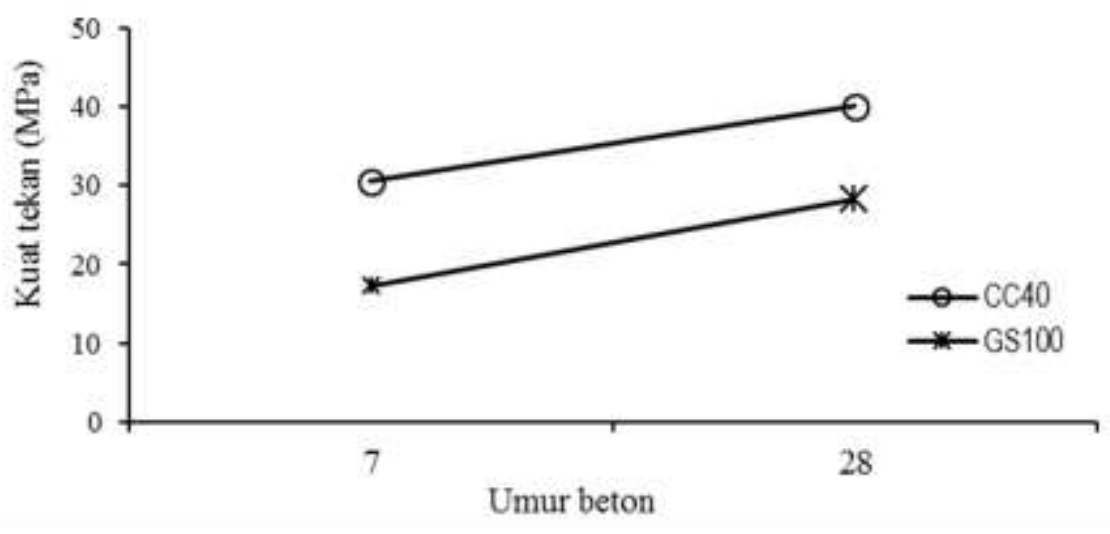

Gambar 2. Peningkatan Kuat Tekan Spesimen GS100 


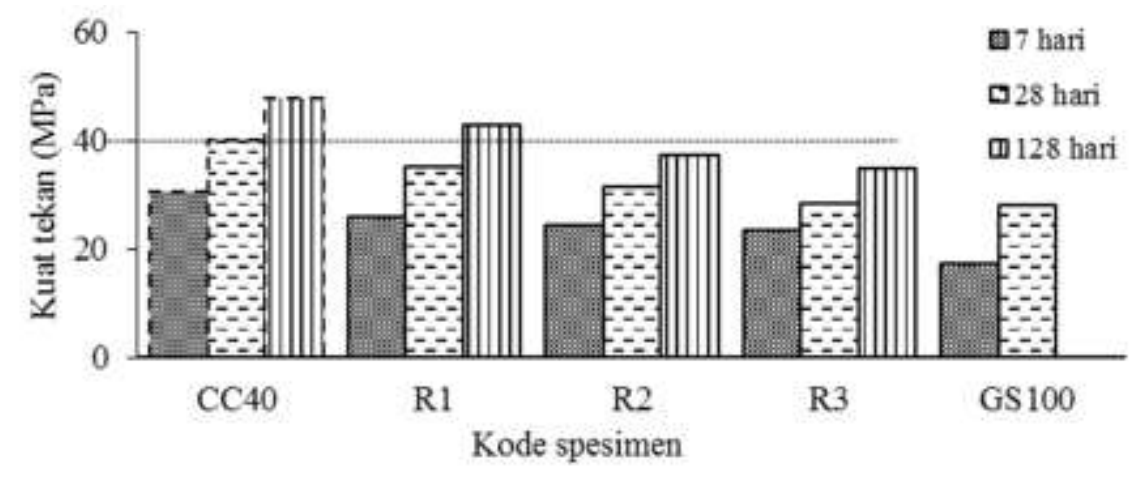

Gambar 3. Kuat Tekan Beton Modifikasi

Kuat tarik spesimen GS100 berkurang sekitar $30 \%$ dibandingkan dengan beton original. Hal ini disebabkan karena seluruh porsi pasir alam digantikan dengan partikel gelas. Penggantian seluruh volume pasir alam dengan GS menyebabkan spesimen GS100 menghasilkan kapasitas tarik terendah dibandingkan modifikasi lainnya pada usia 28 hari seperti yang ditunjukkan pada Gambar 5. Partikel pasir alam alam memiliki permukaan kasar yang lebih merata dan tersebar di seluruh permukaannya dibandingkan dengan tekstur permukaan partikel kaca yang memiliki sisi dan sudut-sudut ekstrim. Dengan kondisi permukaan yang demikian, partikel GS lebih sulit

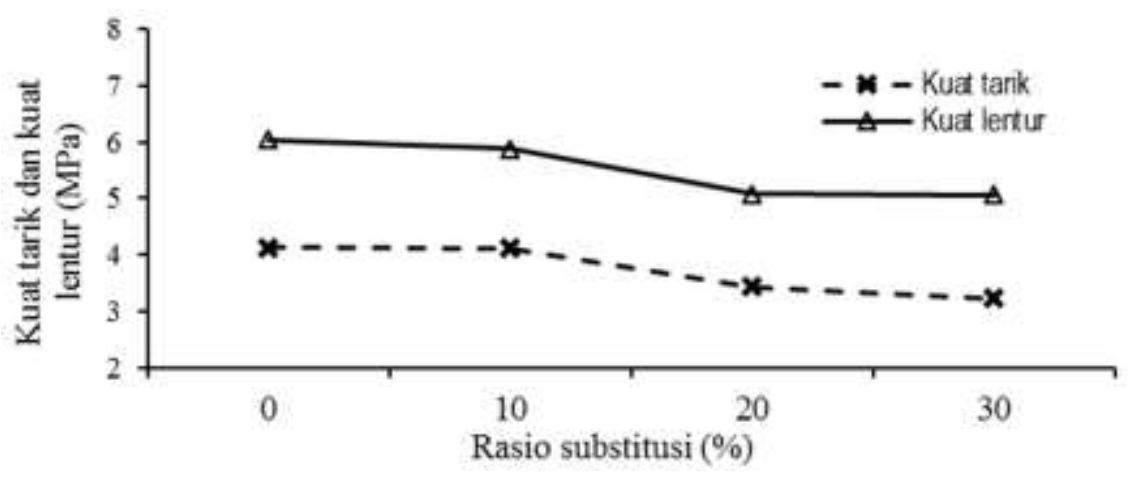

Gambar 4. Kuat Tarik Spesimen R1, R2, R3 Pada Umur 28 Hari

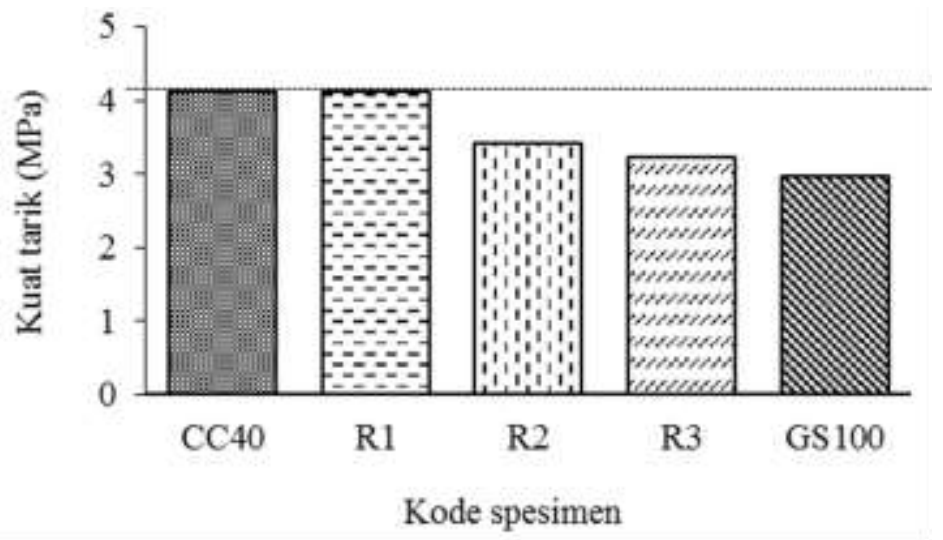

Gambar 5. Kuat Tarik Beton Modifikasi Pada Umur 28 Hari 
mengalami proses pengikatan dengan pasta semen yang pada akhirnya meningkatkan jumlah retak tarik (tensile cracking) di dalam beton.

\section{Kuat Lentur}

Pada Gambar 4, kapasitas lentur spesimen R1 dan R2 berkurang masingmasing 3\% dan $16 \%$. Hasil ini selaras dengan penelitian yang dilakukan oleh Thomas et al. (2014). Perubahan yang tidak substansial pada spesimen R1 ini menunjukkan bahwa pemanfaatan partikel karet bekas dalam jumlah kecil mampu mengimbangi kekuatan tarik selayaknya beton normal pada usia 28 hari. Sedangkan proporsi penggantian pasir dengan TS sebanyak 20\% dan $30 \%$ tidak menyebabkan perubahan kuat tarik pada spesimen R2 dan R3 seperti yang diilustrasikan dalam Gambar 6.

Penggunaan GS sebagai substitusi menyeluruh pasir natural dalam adukan beton spesimen GS100 memperburuk daya tahan beton terhadap beban lentur. Kuat lentur spesimen ini menurun drastis sekitar $34 \%$ seperti terlihat pada Gambar 6. Kondisi ini secara linier sesuai dengan pengamatan yang dilakukan oleh Ali dan Al-Tersawy (2012). Meskipun terdapat perbedaan penurunan kuat lentur, partikel kaca dengan permukaan licin, bentuk angular dan daya serap air yang rendah sebagai penghambat reaksi antara partikel kaca dan matriks semen merupakan faktor penyebab utama penurunan kapasitas lentur.

\section{Penyerapan Air}

Penyelidikan tentang daya serap air hanya dilakukan pada spesimen CC40, R1, R2, dan R3. Secara umum, semakin kecil kandungan partikel karet dalam beton maka makin rendah daya serap air beton yang dihasilkan. Spesimen R1 menyerap hanya $3.47 \%$ air dibandingkan CC40 sebesar 3.61\%. Sementara itu meskipun perubahan daya serap air pada spesimen R2 dan R3 hanya $0.03 \%$, jumlah air yang masuk ke dalam inti beton pada kedua spesimen ini melebihi beton normal.

Karakteristik kekuatan dan daya serap air beton normal dan beton modifikasi secara keseluruhan diilustrasikan dalam grafik dengan ordinat ganda yang ditunjukkan dalam Gambar 8. Secara umum kekuatan dan daya serap air beton modifikasi yang sebanding dengan beton konvensional dicapai oleh spesimen R1 dan terendah oleh spesimen GS100.

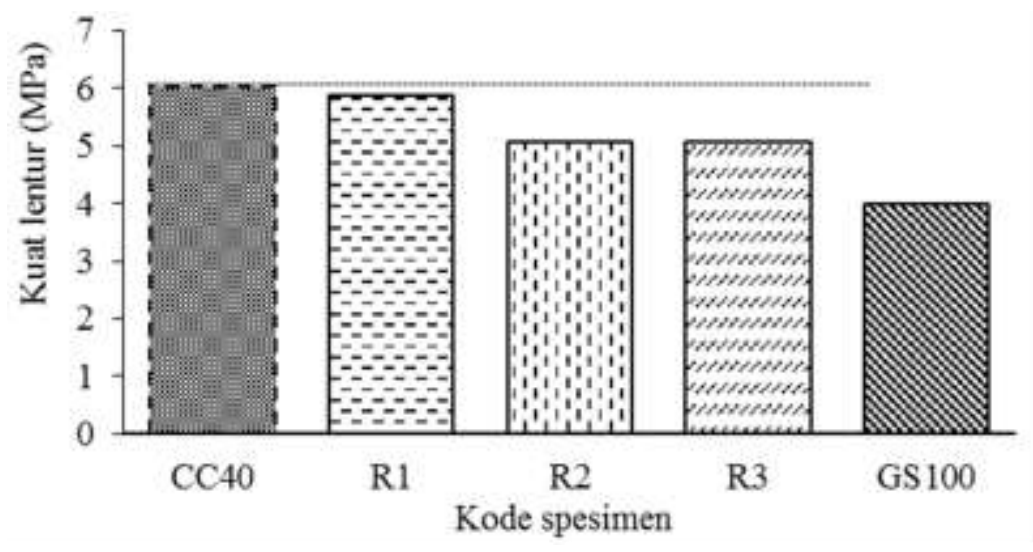

Gambar 6. Kuat Lentur Beton Modifikasi Pada Umur 28 Hari 


\section{KESIMPULAN}

Pemanfaatan material bekas pakai sebagai alternatif komposisi beton secara umum mereduksi karakteristik fisik dan mekanis beton dan karakteristik beton mengalami degradasi yang lebih ekstrim dengan meningkatnya kandungan material alternatif. Penggantian material pasir alam dengan partikel karet dalam rasio kecil menghasilkan kapasitas tekan, tarik dan lentur yang lebih baik dibandingkan dengan penggantian dalam jumlah lebih besar. Beton dengan kandungan partikel karet minimal dapat mempertahankan tingkat daya serap air yang lebih baik dibandingkan beton konvensional. Substitusi menyeluruh atas pasir alam dengan material alternatif menurunkan daya lekat antar partikel dalam campuran sehingga menurunkan kekuatan beton secara signifikan.

\section{DAFTAR PUSTAKA}

Ali EE, Al-Tersawy SH. 2012. Recycled Glass as a Partial Replacement for Fine Aggregate in Self Compacting Concrete. Construction and Building Materials. 35: 785-791.

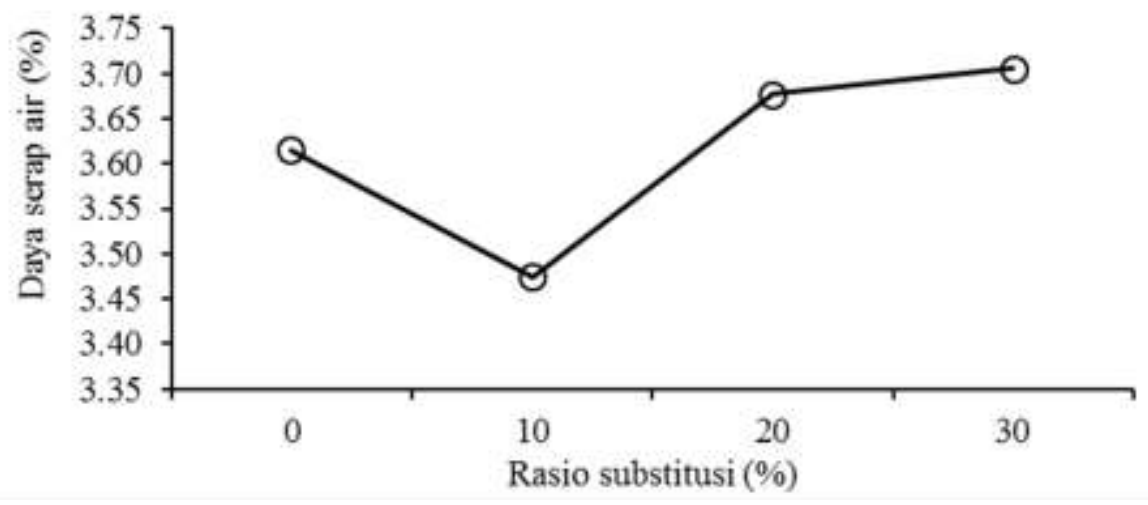

Gambar 7. Daya Serap Air Spesimen R1, R2 dan R3

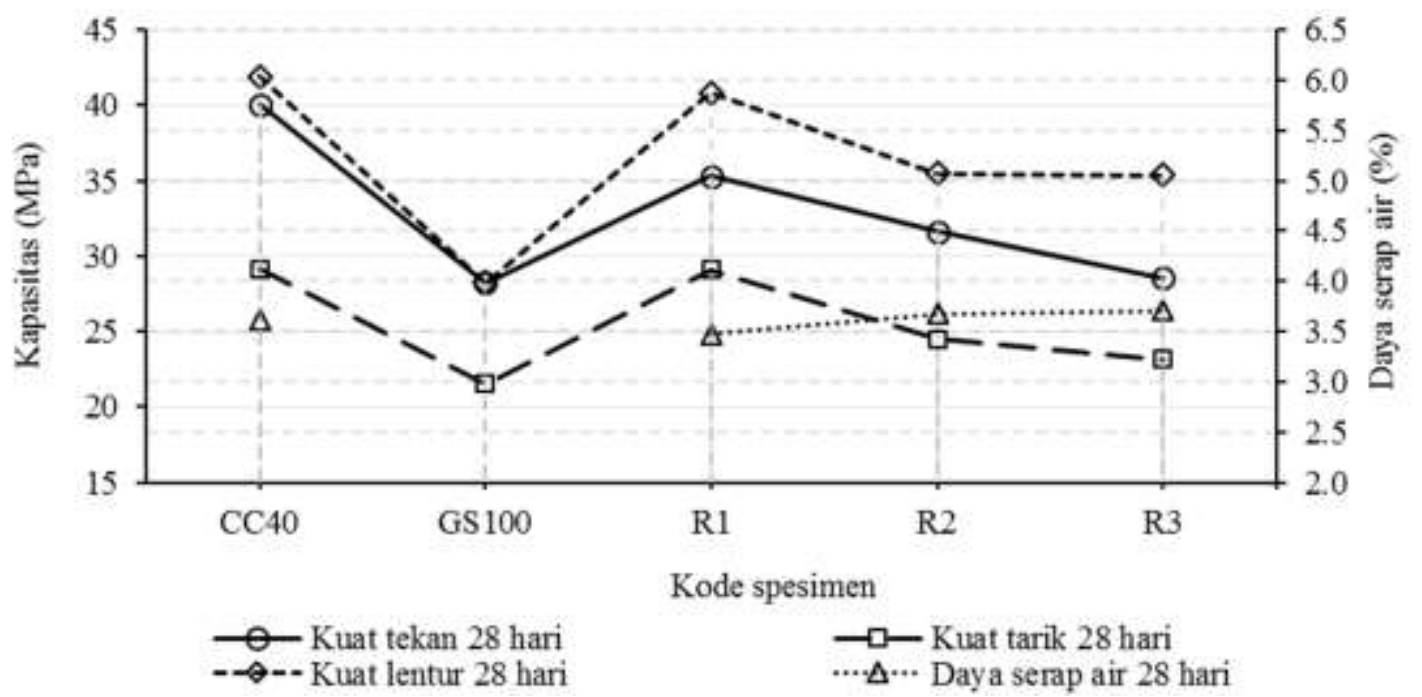

Gambar 8. Karakteristik Kekuatan dan Daya Serap Air Beton Modifikasi 
Batayneh M, Marie I, Asi I. 2007. Use of Selected Waste Materials in Concrete Mixes. Waste Management. 27(12): 1870-1876.

Batayneh M, Marie I, Asi I. 2008. Promoting the Use of Crumb Rubber Concrete in Developing Countries. Waste Management. 28(11): 2171-2176.

Borhan TM. 2012. Properties of Glass Concrete Reinforced with Short Basalt Fibre. Materials \& Design. 42: 265-271.

Bravo M, Brito JD. 2012. Concrete Made with Used Tyre Aggregate: Durability-related Performance. Journal of Cleaner Production. 25: 42-50.

Ismail ZZ, Al-Hashmi EA. 2009. Recycling of Waste Glass as a Partial Replacement for Fine Aggregate in Concrete. Waste Management. 29(2): 655-659.

Kou SC, Poon CS. 2009. Properties of Self-compacting Concrete Prepared with Recycled Glass Aggregate. Cement and Concrete Composites. 31(2): 107-113.

Limbachiya MC. 2009. Bulk Engineering and Durability Properties of Washed Glass Sand Concrete. Construction and Building Materials. 23(2): 1078-1083.

Ling TC, Poon CS. 2011. Utilization of Recycled Glass Derived from Cathode Ray Tube Glass as Fine Aggregate in Cement Mortar. Journal of Hazardous Materials. 192(2): 451-456.

Malik MI et al. 2013. Study of Concrete Involving Use of Waste Glass as Partial Replacement of Fine Aggregates. IOSR Journal of Engineering. 3(7): 8-13.

Nithiya P, Portchejian G. 2014. Behaviour of Partial Replacement of Fine Aggregate with Crumb Rubber Concrete. International Journal of Structural and Civil Engineering Research. 3: 63-72.
Oliver JGJ, Maenhout GJ, Muntean M. 2014. Trends in Global CO2 Emissions: 2014 Report.

Segre N, Joekes I. 2000. Use of Tire Rubber Particles as Addition to Cement Paste. Cement and Concrete Research. 30(9): 1421-1425.

Shayan A, Xu A. 2004. Value-added Utilisation of Waste Glass in Concrete. Cement and Concrete Research. 34(1): 81-89.

Shayan A, Xu A. 2006. Performance of Glass Powder as a Pozzolanic Material in Concrete: A Field Trial on Concrete Slabs. Cement and Concrete Research. 36(3): 457-468.

Siddique R, Naik TR. 2004. Properties of Concrete Containing Scrap-tire Rubber - An Overview. Waste Management. 24(6): 563-569.

Taha B, Nounu G. 2008. Properties of Concrete Contains Mixed Colour Waste Recycled Glass as Sand and Cement Replacement. Construction and Building Materials. 22(5): 713-720.

Thomas BS et al. 2014. Strength, Abrasion and Permeation Characteristics of Cement Concrete Containing Discarded Rubber Fine Aggregates. Construction and Building Materials. 59: 204-212.

Vu DC, Turatsinze A, Ho AC. 2008. On the Potential of Rubber Aggregates Obtained by Grinding End-of-life Tyres to Improve the Strain Capacity of Concrete. Concrete Repair, Rehabilitation and Retrofitting II. CRC Press. 95-96.

Warudkar AA, Valekar NS. 2015. A Technical and Economical Assessment of Replacement of Coarse Aggregate By Waste Tyre Rubber in Construction. International Journal of Engineering Research and General Science. 3:754766. 
Yung WH, Yung LC, Hua LH. 2013. A

Study of the Durability Properties of Waste Tire Rubber Applied to Selfcompacting Concrete. Construction and Building Materials. 41: 665-672. 